\title{
The removal of uranium onto carbon-supported nanoscale zero-valent iron particles
}

\author{
Richard A. Crane · Thomas Scott
}

Received: 13 May 2014/Accepted: 10 December 2014/Published online: 23 December 2014

(C) The Author(s) 2014. This article is published with open access at Springerlink.com

\begin{abstract}
In the current work carbon-supported nanoscale zero-valent iron particles (CS nZVI), synthesised by the vacuum heat treatment of ferric citrate trihydrate absorbed onto carbon black, have been tested for the removal of uranium (U) from natural and synthetic waters. Two types of CS nZVI were tested, one vacuum annealed at $600{ }^{\circ} \mathrm{C}$ for $4 \mathrm{~h}$ and the other vacuum annealed at $700{ }^{\circ} \mathrm{C}$ for $4 \mathrm{~h}$, with their $\mathrm{U}$ removal behaviour compared to nZVI synthesised via the reduction of ferrous iron using sodium borohydride. The batch systems were analysed over a 28-day reaction period during which the liquid and nanoparticulate solids were periodically analysed to determine chemical evolution of the solutions and particulates. Results demonstrate a well-defined difference between the two types of CS nZVI, with greater $\mathrm{U}$ removal exhibited by the nanomaterial synthesised at $700{ }^{\circ} \mathrm{C}$. The mechanism has been attributed to the CS nZVI synthesised at $700{ }^{\circ} \mathrm{C}$ exhibiting (i) a greater proportion of surface oxide $\mathrm{Fe}^{2+}$ to $\mathrm{Fe}^{3+}(0.34$ compared to 0.28$)$; (ii) a greater conversion of ferric citrate trihydrate $\left[2 \mathrm{Fe}\left(\mathrm{C}_{6}\right.\right.$ $\left.\mathrm{H}_{5} \mathrm{O}_{7}\right) \cdot \mathrm{H}_{2} \mathrm{O}$ ] to $\mathrm{Fe}^{0}$; and (iii) a larger surface area (108.67 compared to $88.61 \mathrm{~m}^{2} \mathrm{~g}^{-1}$ ). Lower maximum $\mathrm{U}$ uptake was recorded for both types of CS nZVI in comparison with the borohydride-reduced nZVI. A
\end{abstract}

R. A. Crane $(\varangle) \cdot$ T. Scott

School of Physics, Interface Analysis Centre, University

of Bristol, Bristol, UK

e-mail: richardandrewcrane@gmail.com;

Richard.Crane@bristol.ac.uk lower decrease in solution Eh and DO was also recorded, indicating that less chemical reduction of $\mathrm{U}$ was achieved by the CS nZVI. Despite this, lower U desorption in the latter stages of the experiment (>7 days) was recorded for the CS nZVI synthesised at $700{ }^{\circ} \mathrm{C}$, indicating that carbon black in the CS nZVI is likely to have contributed towards $\mathrm{U}$ sorption and retention. Overall, it can be stated that the borohydridereduced nZVI were significantly more effective than CS nZVI for U removal over relatively short timescales (e.g. $<48 \mathrm{~h}$ ), however, they were more susceptible to $\mathrm{U}$ desorption over extended time periods.

Keywords Nanoparticles - Zero-valent iron · Carbon black $\cdot$ Uranium $\cdot$ Remediation

\section{Introduction}

In recent years, nanoscale zero-valent iron particles (nZVI) have been investigated as a new tool for waste water treatment (Zhang 2003). Compared to ZVI commonly used in permeable reactive barriers (particle diameter $>0.1 \mu \mathrm{m})$, (Cantrell et al. 1995) nZVI have a significantly greater surface area to volume ratio, and resultantly, considerably enhanced reactivity with regard to contaminants (Zhang 2003). Their colloidal size also makes their deployment flexible due to their conceptually high mobility through porous media and their potential for injection at almost any location and depth in terrestrial groundwater systems (Crane and 
Scott 2012; Crane and Noubactep 2012). An intrinsic technical challenge, however, associated with the in situ immobilisation of metal and metalloid contaminants onto nZVI is the prospect for contaminant remobilisation (Crane and Scott 2012; Crane et al. 2015; Shin et al. 2013). This behaviour was recently documented by Crane et al. (2011), where nZVI were tested for the removal of $U$ from dissolved oxygen (DO) bearing groundwater also containing a high concentration (>500 $\mathrm{m} \mathrm{L} \mathrm{L}^{-1}$ ) of dissolved bicarbonate. The nZVI were determined as initially effective for the removal of $\mathrm{U}$, with $>98 \%(<10 \mu \mathrm{g} / \mathrm{L})$ removal achieved within $2 \mathrm{~h}$ of reaction. However, over extended time periods ( $>7$ days), significant $(>50 \%)$ re-release was recorded. The mechanism was attributed to incomplete chemical reduction of surface-precipitated $U$ (from soluble $U^{6+}$ to insoluble $\mathrm{U}^{4+}$ ), allowing the re-release of $\mathrm{U}$ concurrent with the re-ingress of DO and the subsequent reformation of highly stable (nominally carbonate) aqueous U-complexes. Indeed it has been demonstrated for circumneutral $\mathrm{pH}$ solutions lacking complexing agents (i.e. uranyl solution with conservative background electrolyte) near-total chemical reduction of $\mathrm{U}^{6+}$ to $\mathrm{UO}_{2}$ (s) upon the surface of nZVI can occur (Riba et al. 2008), whereas the chemical reduction of $\mathrm{U}^{6+}$ is suppressed in solutions containing carbonate (Yan et al. 2010; Crane et al. 2011; Crane and Scott. 2014). Indeed O'Loughlin et al. (2003) confirmed that $\mathrm{U}^{6+}$ can be readily chemically reduced to $\mathrm{U}^{4+}$ by mixed $\mathrm{Fe}^{2+} \beta^{3+}$ (oxy)hydroxide, however, they can also be readily reoxidised when in the presence of DO. Furthermore, Gu et al. (1998) determined that reductively precipitated $\mathrm{U}^{4+}$ on $\mathrm{Fe}^{0}$ can be readily desorbed by introducing a carbonated-rich solution or allowing DO to ingress into the solution. Overall, the studies have highlighted that the utility of nZVI for the in situ removal of $U$ from contaminated groundwater is likely to be restricted to anaerobic conditions since it is otherwise quickly transformed to iron (hydr)oxides under aerobic conditions, with concurrent U release (Crane and Scott 2012; Crane and Scott 2013; Scott et al. 2011; Yan et al. 2014). To address this issue, the use of (meso)porous support materials which provide additional sorption sites to prevent $\mathrm{U}$ desorption is an emerging field of research. Indeed nanocomposite materials may provide novel capability and function for the removal of metal and metalloid species from waste waters, due to the unique dual benefit of chemical reducing capability, facilitated by the nZVI, and high capacity sorption, facilitated by the mesoporous substrate. For example, resin-supported nZVI has been demonstrated to remove $\mathrm{CrO}_{4}{ }^{2-}$ and $\mathrm{Pb}^{2+}$ from aqueous solutions, with removal rates compared to ordinary nZVI enhanced by 5 - and 18 -fold, respectively (Ponder et al. 2000). In addition, nZVI supported by zeolite (Li et al. 2007) and clay minerals (Üzüm et al. 2009; Sheng et al. 2014) have demonstrated improvements in nZVI adsorption capacity. Mesoporous carbon (MC) exhibits unique physical (pore size distribution and surface area) and chemical functionality (Rahman et al. 2011) and has therefore received considerable interest as a candidate support material for nZVI. Materials investigated to date include granular-activated carbon-supported nZVI (Choi et al. 2009), multi-walled carbon nanotube-supported nZVI (Lv et al. 2011) and graphene-supported nZVI (Jabeen et al. 2011), with significant improvements in aqueous contaminant adsorption/degradation capacity recorded. The efficacy of MC-nZVI for the removal of $U$, however, remains a relatively unexplored research field, despite MC being well demonstrated as highly effective for U removal (Abbasi and Streat 1994; Chen et al. 2007; Kumar et al. 2011; Mellah et al. 2006; Wang et al. 2012). For example, to date there exists one study investigating the removal of $\mathrm{U}^{6+}$ onto reduced graphene oxide-supported nZVI with results demonstrating simultaneous $\mathrm{U}^{6+}$ adsorption and chemical reduction, along with significantly higher $U$ removal capacity than unmodified nZVI (Suna et al. 2014). The comparative efficacies of numerous other forms of MC-nZVI are yet to be investigated. Carbon black is a low cost and abundant waste product from the fossil fuel industry and has been demonstrated as a suitable substrate material for the carbothermal synthesis of carbon-supported nZVI (Hoch et al. 2008). Analogous to the production of $\mathrm{Fe}^{0}$ from iron ore, the method regards the carbothermal reduction $\left(>500{ }^{\circ} \mathrm{C}\right)$ of $\mathrm{Fe}^{2+}$ adsorbed onto carbon black. In addition, despite the high temperatures $\left(>500{ }^{\circ} \mathrm{C}\right)$ required for the formation of $\mathrm{Fe}^{0}$ in preference to its oxides, the reaction is endothermic, with only gaseous by-products $\left(\mathrm{H}_{2}, \mathrm{CO}, \mathrm{CO}_{2}\right.$, etc.), and therefore represents an easily scalable process.

Carbon black-supported nZVI (CS nZVI) are tested in the current work for the removal of $U$ from mine water and synthetic uranyl solutions. The work has been established in order to determine the differential $U$ uptake behaviour of CS nZVI compared to conventional borohydride-reduced $\mathrm{nZVI}$ in solutions containing DO. 


\section{Materials and methods}

Chemicals

All chemicals (carbon black, iron sulphate $\left(\mathrm{FeSO} 4 \cdot 7 \mathrm{H}_{2-}\right.$ $\mathrm{O})$, ferric citrate trihydrate $\left[2 \mathrm{Fe}\left(\mathrm{C}_{6} \mathrm{H}_{5} \mathrm{O}_{7}\right) \cdot \mathrm{H}_{2} \mathrm{O}\right]$, nitric acid $\left(\mathrm{HNO}_{3}\right)$, sodium borohydride $\left(\mathrm{NaBH}_{4}\right)$, sodium hydroxide $(\mathrm{NaOH})$, uranyl acetate $\left[\mathrm{UO}_{2}\left(\mathrm{CH}_{3} \mathrm{COO}\right)_{2-}\right.$ $2 \mathrm{H}_{2} \mathrm{O}$ ] and solvents [ethanol, acetone)] used in this study were of analytical grade and all solutions were prepared using Milli-Q purified water (resistivity $>18.2 \mathrm{M} \Omega \mathrm{cm}$ ). Carbon black (acetylene, $100 \%$ compressed, $99.9+\%$ ), surface area $\sim 75 \mathrm{~m}^{2} / \mathrm{g}$, bulk density 170-230 g/L was purchased from Alfa Aesar (CAS 1333-86-4).

Nanoparticle synthesis

Carbon-supported nZVI were synthesised following an adaptation of the method described by Hoch et al. (2008). $37.01 \mathrm{~g}$ of ferric citrate trihydrate $\left[2 \mathrm{Fe}\left(\mathrm{C}_{6} \mathrm{H}_{5}\right.\right.$ $\left.\left.\mathrm{O}_{7}\right) \cdot \mathrm{H}_{2} \mathrm{O}\right]$ and $5 \mathrm{~g}$ of carbon black were combined in $500 \mathrm{~mL}$ of Milli-Q water (resistivity $18.2 \mathrm{M} \Omega \mathrm{cm}$ at $25{ }^{\circ} \mathrm{C}$ ) and stirred overnight using a DOS-10L Skyline autoshaker at 90 RPM. The resultant nanoparticle slurry was then decanted into $10-\mathrm{mL}$ centrifuge vials and centrifuged in a Hamilton Bell Vanguard V6500 desktop centrifuge at $6,500 \mathrm{RPM}$ for $30 \mathrm{~s}$. The supernatant was then discarded and the wet nanoparticle powder was transferred into a vacuum desiccator and dried for $48 \mathrm{~h}$ at $1 \times 10^{-3}$ mbar. The resulting particulates were then separated into two separate 2 -g batches and heated under vacuum $\left(<1 \times 10^{-3}\right.$ mbar $)$ at 600 and $700{ }^{\circ} \mathrm{C}$, respectively, for $4 \mathrm{~h}$ with a heating and cooling ramp rate of approximately $10{ }^{\circ} \mathrm{C} \mathrm{min}^{-1}$. $\mathrm{Fe}^{0}$ is considered to form via the following reactions (Eqs. 1, 2).

$$
\begin{aligned}
& 2 \mathrm{Fe}\left(\mathrm{C}_{6} \mathrm{H}_{5} \mathrm{O}_{7}\right) \cdot \mathrm{H}_{2} \mathrm{O}_{(\mathrm{s})}+\mathrm{C}_{(\mathrm{s})} \\
& \rightarrow 2 \mathrm{Fe}_{(\mathrm{s})}^{0}+2 \mathrm{C}_{3} \mathrm{H}_{2} \mathrm{O}_{(\mathrm{s})}+6 \mathrm{CO}_{2(\mathrm{~g})}+\mathrm{CO}_{(\mathrm{g})} \\
& +5 \mathrm{H}_{2} \mathrm{O}_{(\mathrm{l})} \\
& \mathrm{Fe}_{3} \mathrm{O}_{4(\mathrm{~s})}+2 \mathrm{C}_{(\mathrm{s})} \rightarrow 3 \mathrm{Fe}_{(\mathrm{s})}^{0}+2 \mathrm{CO}_{2(\mathrm{~g})}
\end{aligned}
$$

The resultant nanopowders were then stored in sealed containers in a nitrogen-filled (BOC, $99.998 \%$ ) glovebox (Saffron Scientific, Alpha series) until required.
Borohydride-reduced nZVI were synthesised following the method described by Wang and Zhang (1997), using sodium borohydride to reduce ferrous iron to a metallic state. $7.65 \mathrm{~g}$ of $\mathrm{FeSO}_{4} \cdot 7 \mathrm{H}_{2} \mathrm{O}$ was dissolved in $50 \mathrm{~mL}$ of Milli-Q water and then a $4 \mathrm{M}$ $\mathrm{NaOH}$ solution was used to adjust the solution $\mathrm{pH}$ to 6.8. The addition of $\mathrm{NaOH}$ was performed slowly, dropwise, to avoid the formation of hydroxocarbonyl complexes. The salts were reduced to metallic nanoparticles by the addition of $3.0 \mathrm{~g}$ of $\mathrm{NaBH}_{4}$. The nanoparticle product was isolated through centrifugation (Hamilton Bell v6500 Vanguard centrifuge, 6,500 RPM for $2 \mathrm{~min}$ ) and then sequentially washed with water, ethanol and acetone ( $20 \mathrm{~mL}$ of each). The nanoparticles were then dried in a vacuum desiccator for $48 \mathrm{~h}$ at $1 \times 10^{-3} \mathrm{mbar}$ and stored in sealed containers in a nitrogen-filled (BOC, $99.998 \%$ ) glovebox (Saffron Scientific, Alpha series) until required.

The mine water effluent

The mine water used in the current study was taken from the Lişava uranium mine, Banat, Romania. The mine site is valley confined and bounded by limestone ridges which contribute significant concentrations of dissolved bicarbonate to ground and surface waters, a complexing agent that is recognised to considerably enhance U-mobility in natural water systems (Ragnarsdottir and Charlet (2000). The water is used for mining and is pumped from approximately $200 \mathrm{~m}$ below sea level, a depth significantly beneath the water table. It initially contains low concentrations of DO $\left(<3 \mathrm{mg} \mathrm{L}^{-1}\right)$; however, it quickly equilibrates with the atmosphere to reach oxygen concentrations more typical for that of vadose and/or surface waters $\left(\sim 10 \mathrm{mg} \mathrm{L}^{-1}\right)$, changing its redox potential and associated transport properties in the process.

\section{Experimental procedure}

Four 500-mL Schott Duran jars were filled with $400 \mathrm{~mL}$ of the U-bearing mine water effluent. A further four jars were filled with $400 \mathrm{~mL}$ of Milli-Q water with $\mathrm{U}$ at $0.5 \mathrm{mg} \mathrm{L}{ }^{-1}, \mathrm{NaNO}_{3}$ was then added at $0.1 \mathrm{mM}$ as a background electrolyte species and the $\mathrm{pH}$ was adjusted to 8.5 using $0.01 \mathrm{M} \mathrm{NaOH}$. The 
addition of $\mathrm{NaOH}$ was performed slowly, dropwise, to avoid the formation of hydroxocarbonyl complexes. $0.1 \mathrm{~g}$ of each nanoparticle type (borohydride-reduced nZVI, CS nZVI synthesised at $600{ }^{\circ} \mathrm{C}$ and CS nZVI synthesised at $700{ }^{\circ} \mathrm{C}$ ) were then each added to the mine water and the uranyl solutions. Prior to addition, the nanopowders were each suspended in $1 \mathrm{~mL}$ of ethanol (Sigma-Aldrich, $\geq 99.5 \%$ ) and dispersed by sonication for $60 \mathrm{~s}$ using a Fisher Scientific Ultrasonic cleaner. The one remaining mine water solution and uranyl-only solution were retained as nanoparticlefree controls. Systems were sampled at 0, 1, 2, 4, 24, $48 \mathrm{~h}, 7,14,21$ and 28 days. Prior to sampling, the batch systems were gently agitated to ensure homogeneity, and $\mathrm{pH}$ and $\mathrm{Eh}$ measurements were taken using a Hanna Instruments meter (model HI 8424) with a combination of gel electrode $\mathrm{pH}$ probe and a platinum ORP electrode, respectively. DO measurements were also taken using a Jenway $970 \mathrm{DO}_{2}$ metre. Aliquots of $10 \mathrm{~mL}$ were also taken from each batch system and centrifuged using a Hamilton Bell Vanguard V6500 desktop centrifuge at 6,500 rpm for $30 \mathrm{~s}$ to separate the liquid and solid phases. The liquid was decanted, filtered through a $0.22-\mu \mathrm{m}$ cellulose acetate filter and then prepared for ICP-AES and ICP-MS.

Sample analysis methods

\section{Bet}

In preparation for BET surface area analysis, samples were degassed under vacuum $\left(1 \times 10^{-2} \mathrm{mbar}\right)$ for a 12-h period at a temperature of $75^{\circ} \mathrm{C}$. A known weight of the dried material was measured with a Quantachrome NOVA 1200 surface area analyser, using $\mathrm{N}_{2}$ as the adsorbent and following a 7-point BET method.

\section{ICP-AES preparation and conditions}

The liquid samples were prepared for ICP-AES analysis by a 10 times dilution in $1 \%$ nitric acid (analytical quality concentrated $\mathrm{HNO}_{3}$ in Milli-Q water). Blanks and standards for analysis were also prepared in $1 \%$ nitric acid, with Fe standards of 0.10 , $0.25,0.50,1.00,2.50,5.0$ and $10.0 \mathrm{mg} \mathrm{L}^{-1}$. A JobinYvon Ultima ICP-AES (sequential spectrometer) fitted with a cyclone spray chamber and a Burgener Teflon Mira mist nebulizer was used. The $\mathrm{Fe}$ concentration was measured using the emission line at $259.94 \mathrm{~nm}$.

\section{ICP-MS preparation and conditions}

Samples from each batch system were prepared for ICP-MS analysis by a 20 times dilution in $1 \%$ nitric acid (analytical quality concentrated $\mathrm{HNO}_{3}$ in Milli-Q water). Blanks and U standards at 1.0, 2.0, 10, 20 and $50 \mu \mathrm{g} \mathrm{L}^{-1}$ were also prepared in $1 \%$ nitric acid. An internal Bi standard of $10 \mu \mathrm{g} \mathrm{L}^{-1}$ was added to blanks, standards and samples. The ICP-MS instrument used was a VG Thermo Elemental PQ 3.

\section{Transmission electron microscopy}

TEM images were obtained with a JEOL JEM 1200 EX Mk 2 TEM, operating at $120 \mathrm{keV}$. Nanoparticle samples were mounted on 200 mesh holey carboncoated copper grids.

\section{$X$-ray diffraction}

A Phillips Xpert Pro diffractometer with a $\mathrm{Cu}_{\mathrm{K} \alpha}$ radiation source $(\lambda=1.5406 \AA)$ was used for XRD analysis (generator voltage of $40 \mathrm{keV}$; tube current of $30 \mathrm{~mA}$ ). XRD spectra were acquired between $2 \theta$ angles of $0-90^{\circ}$, with a step size of $0.02^{\circ}$ and a $2-\mathrm{s}$ dwell time.

\section{$X$-ray photoelectron spectroscopy}

A Thermo Fisher Scientific Escascope equipped with a dual anode X-ray source $\left(\mathrm{Al}_{\mathrm{K} \alpha} 1,486.6 \mathrm{eV}\right.$ and $\mathrm{Mg}_{\mathrm{K} \alpha}$ $1,253.6 \mathrm{eV}$ ) was used for XPS analysis. Samples were analysed at $<5 \times 10^{-8}$ mbar with $\mathrm{Al}_{\mathrm{K} \alpha}$ radiation of $300 \mathrm{~W}(15 \mathrm{kV}, 20 \mathrm{~mA})$ power. High-resolution scans were acquired using a $30 \mathrm{eV}$ pass energy and 300-ms dwell times. Following the acquisition of survey spectra over a wide binding energy range, the Fe $2 p$, $\mathrm{C} 1 \mathrm{~s}, \mathrm{O} 1 \mathrm{~s}$ and $\mathrm{U} 4 \mathrm{f}$ spectral regions were then scanned at a higher energy resolution such that valence state determinations could be made for each element. Data analysis was carried out using Pisces software (Dayta Systems Ltd.) with binding energy values of the recorded lines referenced to the adventitious hydrocarbon $\mathrm{C} 1 \mathrm{~s}$ peak at $284.8 \mathrm{eV}$. In order to determine the relative proportions of $\mathrm{Fe}^{2+}$ and $\mathrm{Fe}^{3+}$ in the sample analysis volume, curve fitting of the 
recorded Fe $2 \mathrm{p}$ photoelectron peaks was performed following the method of Grosvenor et al. (2004). The $\mathrm{Fe} 2 \mathrm{p}$ profile was fitted using photoelectron peaks at 706.7, 709.1, 710.6 and $713.4 \mathrm{eV}$ corresponding to $\mathrm{Fe}^{0}, \mathrm{Fe}_{\text {octahedral }}^{2+}, \mathrm{Fe}_{\text {octahedral }}^{3+}$ and $\mathrm{Fe}_{\text {tetrahedral }}^{3+}$ These parameters were selected on the basis that the surface oxide was assumed to be a mixture of wüstite and magnetite, as the oxide $\mathrm{Fe}^{2+}$ is in the same coordination with the surrounding oxygen atoms in both forms of oxide.

\section{Results}

Preliminary characterisation of the U-bearing mine water

Prior to nanoparticle addition, the U-bearing mine water was characterised using ICP-AES ( $\mathrm{Fe}, \mathrm{Mg}, \mathrm{Cu}$ and $\mathrm{Mo}$ ), ICP-MS (U), volumetric titration $\left(\mathrm{HCO}_{3}{ }^{-}\right.$, $\mathrm{NO}_{3}{ }^{-}$and $\left.\mathrm{PO}_{4}{ }^{3-}\right)$ and gravimetry $\left(\mathrm{SO}_{4}{ }^{2-}\right)$ with supplementary $\mathrm{Eh}, \mathrm{pH}$ and DO measurements, Table 1 . The analysis indicated that $\mathrm{HCO}_{3}{ }^{-}$, welldocumented to form uranyl complexes of high thermodynamic stability (Ragnarsdottir and Charlet 2000) was the most common ligand species present, with a concentration of $624 \mathrm{ppm}$.

\section{Preliminary characterisation of nanoparticles}

Vacuum annealing temperatures of 600 and $700{ }^{\circ} \mathrm{C}$ were used in the current work for the formation of CS nZVI in order to form $\mathrm{Fe}^{0}$ in preference to its oxides (Hoch et al. 2008). BET surface area analysis recorded a lower surface area for iron citrate sorbed onto carbon black in comparison with the original carbon black material (from 71.05 to $41.07 \mathrm{~m}^{2} \mathrm{~g}^{-1}$ ), Table 2. This is ascribed to a decrease in the porosity of the carbon black due to the adsorption of iron citrate. An increase in the surface area of the CS nZVI was recorded, however, as a result of vacuum annealing; with 59.06 and $63.96 \mathrm{~m}^{2} \mathrm{~g}^{-1}$ recorded for nanoparticles annealed for $2 \mathrm{~h}$ at 600 and $700{ }^{\circ} \mathrm{C}$, respectively, Table 2 . A further increase in CS nZVI surface area was also recorded for the nanoparticles vacuum annealed for $4 \mathrm{~h}$, with 88.61 and $108.67 \mathrm{~m}^{2} \mathrm{~g}^{-1}$ recorded for CS nZVI 600 and $700{ }^{\circ} \mathrm{C}$, respectively. This behaviour is ascribed to the decomposition of the carbon black material and the concurrent formation of nZVI
Table 1 Concentrations of notable chemical species present in the mine water, analysed by ICP-MS (U), ICP-AES (Fe, Mg, $\mathrm{Cu}$ and $\mathrm{Mo})$, volumetric titration $\left(\mathrm{HCO}_{3}{ }^{-}, \mathrm{NO}^{3-}\right.$ and $\mathrm{PO}_{4}{ }^{3-}$ ) and gravimetry $\left(\mathrm{SO}_{4}^{2-)}\right.$ along with the recorded $\mathrm{Eh}, \mathrm{pH}$ and $\mathrm{DO}$

\begin{tabular}{ll}
\hline Chemical species & Concentration (ppm) \\
\hline Cations & \\
$\mathrm{Cu}$ & 0.043 \\
$\mathrm{Fe}$ & 0.019 \\
$\mathrm{Mg}$ & 16.18 \\
$\mathrm{Mo}$ & 0.031 \\
$\mathrm{U}$ & 0.545 \\
$\mathrm{Anions}$ & \\
$\mathrm{HCO}_{3}{ }^{-}$ & 624 \\
$\mathrm{NO}_{3}{ }^{-}$ & 19 \\
$\mathrm{PO}_{4}{ }^{3-}$ & 0.3 \\
$\mathrm{SO}_{4}{ }^{2-}$ & 1.2 \\
$\mathrm{Solution}^{-}$conditions & \\
$\mathrm{DO}^{(p p m)}$ & 11.3 \\
$\mathrm{Eh}^{(m V)}$ & 234 \\
$\mathrm{pH}$ & 8.43 \\
\hline
\end{tabular}

Table 2 Changes in CS nZVI surface area as a function of vacuum annealing temperature and timescale

\begin{tabular}{lc}
\hline Nanoparticle type & $\begin{array}{l}\text { Surface area } \\
\left(\mathrm{m}^{2} \mathrm{~g}^{-1}\right)\end{array}$ \\
\hline Carbon black & 71.05 \\
Carbon-supported nano- $\mathrm{Fe}^{0}$ (before annealing) & 41.07 \\
Carbon-supported nano-Fe $^{0}\left(2 \mathrm{~h} 600^{\circ} \mathrm{C}\right)$ & 59.06 \\
Carbon-supported nano- $\mathrm{Fe}^{0}\left(2 \mathrm{~h} 700^{\circ} \mathrm{C}\right)$ & 63.96 \\
Carbon-supported nano- $\mathrm{Fe}^{0}\left(4 \mathrm{~h} 600^{\circ} \mathrm{C}\right)$ & 88.61 \\
Carbon-supported nano- $\mathrm{Fe}^{0}\left(4 \mathrm{~h} 700^{\circ} \mathrm{C}\right)$ & 108.67 \\
Carbon-supported nano- $^{0} \mathrm{Fe}^{0}\left(12 \mathrm{~h} 600{ }^{\circ} \mathrm{C}\right)$ & 76.31 \\
Carbon-supported nano-Fe $^{0}\left(12 \mathrm{~h} 700^{\circ} \mathrm{C}\right)$ & 39.08 \\
\hline
\end{tabular}

(Eqs. 1, 2.). In contrast, the CS nZVI vacuum annealed for $12 \mathrm{~h}$ exhibited a lower surface area, with 76.31 and $39.08 \mathrm{~m}^{2} \mathrm{~g}^{-1}$ recorded for CS nZVI 600 and $700{ }^{\circ} \mathrm{C}$, respectively. This is attributed to the diffusion bonding of individual nanoparticles during vacuum annealing (Scott et al. 2010; Dickinson et al. 2010). Consequently, for the vacuum annealing timescales tested, a thermal treatment period of $4 \mathrm{~h}$ was found to produce a material of optimal surface area. 
Table 3 A summary of the experimental results regarding the bulk and surface properties of the CS nZVI and the borohydride-reduced nZVI

\begin{tabular}{lllll}
\hline Parameter & & nZVI & $\begin{array}{l}\mathrm{CS} \\
600{ }^{\circ} \mathrm{C}\end{array}$ & $\begin{array}{l}\mathrm{CS} \\
700{ }^{\circ} \mathrm{C}\end{array}$ \\
\hline $\begin{array}{l}\text { Particle size } \\
\text { distribution } \\
(\mathrm{nm})\end{array}$ & $0-50$ & $85 \%$ & $89 \%$ & $91 \%$ \\
$\begin{array}{l}\text { Oxide thickness } \\
(\mathrm{nm})\end{array}$ & $>100$ & $8 \%$ & $6 \%$ & $5 \%$ \\
$\begin{array}{l}\text { BET surface area } \\
\left(\mathrm{m}^{2} / \mathrm{g}\right)\end{array}$ & $7-4 \%$ & $5 \%$ & $4 \%$ \\
$\begin{array}{c}\text { Surface } \\
\text { chemistry }\end{array}$ & $\begin{array}{c}\mathrm{Fe}(0) / \\
\left.\mathrm{Fe}^{2+}+\mathrm{Fe}^{3+}\right)\end{array}$ & 0.05 & $\mathrm{n} / \mathrm{a}$ & 0.02 \\
& $\mathrm{Fe}^{2+} / \mathrm{Fe}^{3+}$ & 0.45 & 0.28 & 0.34 \\
\hline
\end{tabular}

Table 3 lists a summary of the experimental results regarding the bulk and surface properties of the CS nZVI and borohydride-reduced nZVI used for the U sorption experiments. No significant difference in size and/or morphology between the CS nZVI synthesised at 600 and $700{ }^{\circ} \mathrm{C}$ was recorded using TEM (Fig. 1), with both nanoparticle types determined as spherical and within an approximate size range of 20-150 nm. A greater concentration of a dense (dark coloured) crystalline material, however, was recorded for the CS nZVI formed at $700{ }^{\circ} \mathrm{C}$. This is attributed to more complete conversion of ferric citrate trihydrate to $\mathrm{Fe}^{0}$ due to the higher temperature. XPS confirmed the presence of $\mathrm{Fe}^{0}$ within less than approximately $5 \mathrm{~nm}$ from the surface (the XPS analysis depth) for the CS nZVI formed at $700{ }^{\circ} \mathrm{C}$, with a $\mathrm{Fe}^{0} /\left(\mathrm{Fe}^{2+}+\mathrm{Fe}^{3+}\right)$ ratio of 0.02 recorded (Fig. 2). A greater proportion of $\mathrm{Fe}^{2+}$ to $\mathrm{Fe}^{3+}$ was also recorded for the CS nZVI formed at $700{ }^{\circ} \mathrm{C}$, with a ratio of 0.28 and 0.34 recorded for CS nZVI formed at 600 and $700{ }^{\circ} \mathrm{C}$, respectively. XRD confirmed that, as a result of the higher temperature, a greater conversion of iron citrate trihydrate to $\mathrm{Fe}^{0}$ had occurred for the particles synthesised at $700{ }^{\circ} \mathrm{C}$, Fig. 3 .

In comparison between the CS nZVI and the borohydride-reduced nZVI it can be noted that the latter nanomaterials were slightly in diameter (Fig. 1). In addition, the borohydride-reduced nZVI were more agglomerated than the CS nZVI materials, which are attributed to a decrease in the attraction forces (electrosteric and/or magnetic attraction) between individual nanoparticles caused by the presence of the carbon support. XRD analysis of the CS nZVI and the borohydride $\mathrm{nZVI}$ recorded three peaks centred at 44.6, 65.6 and $82.6^{\circ} 2 \theta$, implying the presence of $\mathrm{Fe}^{0}$, with lattice reflections $\mathrm{Fe}(110), \mathrm{Fe}(200)$ and $\mathrm{Fe}(211)$, respectively. It can be noted that the peaks were much broader for the borohydride-reduced nZVI, indicating that the $\mathrm{Fe}^{0}$ is present in a more amorphous state than for the CS nZVI.

Results from sorption experiments

\section{Changes in DO/Eh/pH}

The addition of nanoparticles to the water samples resulted in a rapid decrease in solution Eh for all systems studies; however, chemically reducing conditions was not achieved by either type of CS nZVI (Fig. 5). Similarly, a concurrent rapid decrease in DO was recorded, however, $\mathrm{DO}<2 \mathrm{mg} \mathrm{L}^{-1}$ was not recorded for either CS nZVI type (Fig. 5). In contrast an Eh minima of -530 and $-582 \mathrm{mV}$ was recorded for the mine water and uranyl batch systems, respectively, containing borohydride-reduced nZVI. If we normalise the Eh change to surface area, the borohydride-reduced nZVI show significantly greater redox manipulation than the two CS nZVI types. For borohydride-reduced nZVI, values of 38.9 and $41.6 \mathrm{mV} / \mathrm{m}^{2}$ were recorded for the mine water and uranyl solution, respectively, whilst 2.1 and $1.9 \mathrm{mV} /$ $\mathrm{m}^{2}$ were, respectively, recorded for the CS nZVI synthesised at $700{ }^{\circ} \mathrm{C}$, and 2.0 and $1.7 \mathrm{mV} / \mathrm{m}^{2}$ were recorded for the CS nZVI synthesised at $600{ }^{\circ} \mathrm{C}$.

An accompanying increase in system $\mathrm{pH}$ was recorded for all batch systems (mine water and the uranyl solution) containing the CS nZVI that had formed at $700{ }^{\circ} \mathrm{C}$ and the borohydride-reduced nZVI (Figs. 4, 5). In contrast a decrease in $\mathrm{pH}$ was recorded in both batch systems containing the CS nZVI that had been formed at $600{ }^{\circ} \mathrm{C}$, which is attributed to the dissolution of residual ferric citrate trihydrate $\left[2 \mathrm{Fe}\left(\mathrm{C}_{6} \mathrm{H}_{5} \mathrm{O}_{7}\right) \cdot \mathrm{H}_{2} \mathrm{O}\right]$.

\section{Changes in aqueous $U$ and Fe concentration}

Analysis of aqueous samples extracted during period intervals using ICP-MS recorded limited removal of $U$ in both batch systems (the mine water and the uranylonly solution) treated using CS nZVI that had been formed at $600{ }^{\circ} \mathrm{C}$ (Fig. 6). Improved U removal was 

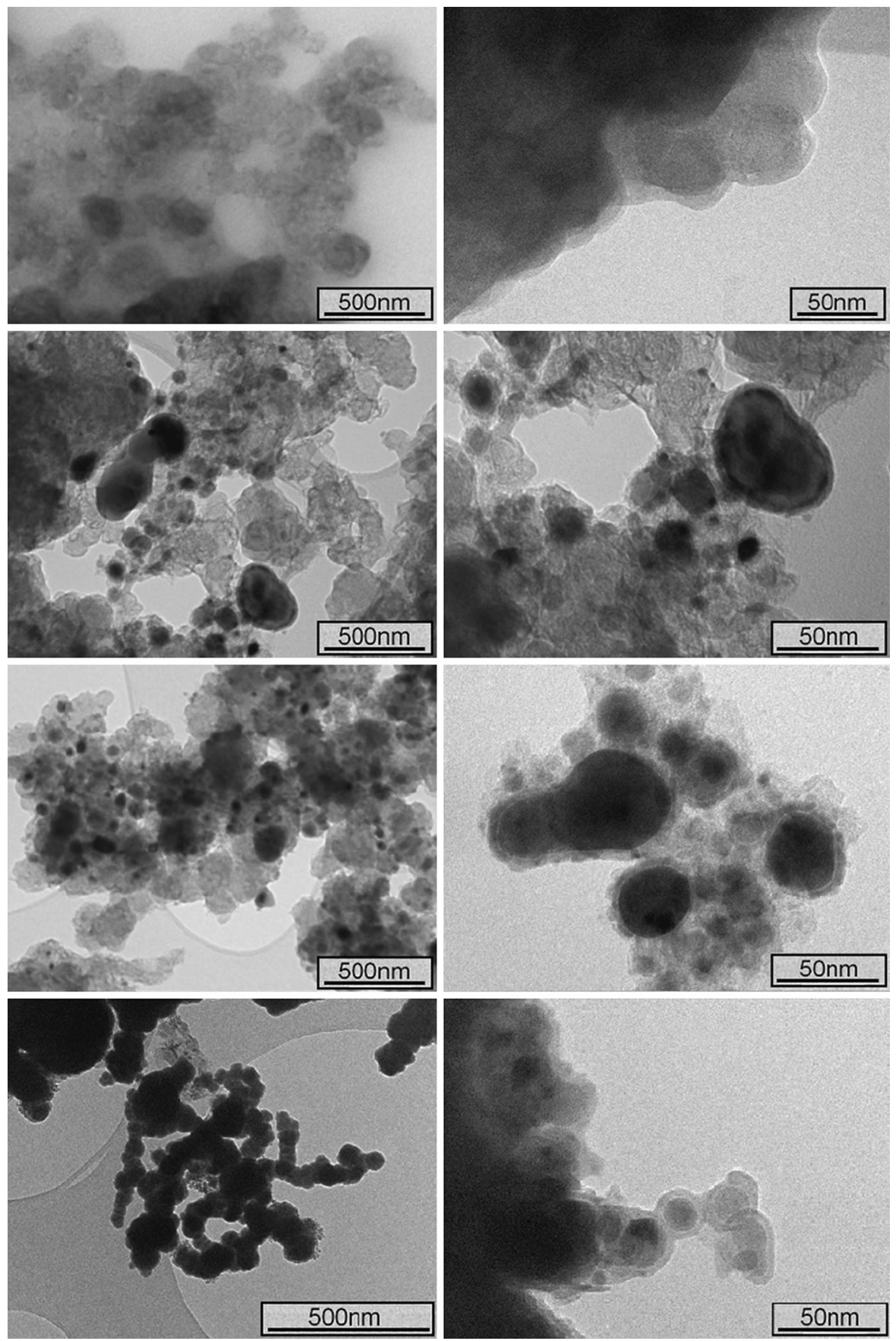

Fig. 1 Transmission electron microscopy (TEM) images of: carbon-supported nZVI before vacuum annealing (top); carbonsupported nZVI after vacuum annealing for $4 \mathrm{~h}$ at $600{ }^{\circ} \mathrm{C}$

exhibited by the CS nZVI that had been formed at $700{ }^{\circ} \mathrm{C}$, with near-total removal of $\mathrm{U}_{(\mathrm{aq})}$ recorded for the uranyl-only solution after $168 \mathrm{~h}$ (1 week) of (second from top); carbon-supported nZVI after vacuum annealing for $4 \mathrm{~h}$ at $700{ }^{\circ} \mathrm{C}$ (third from top); and borohydridereduced nZVI (bottom)

reaction time and maximum removal of $67 \%$ recorded for the mine water after $502 \mathrm{~h}$ ( 3 weeks) of reaction time. 

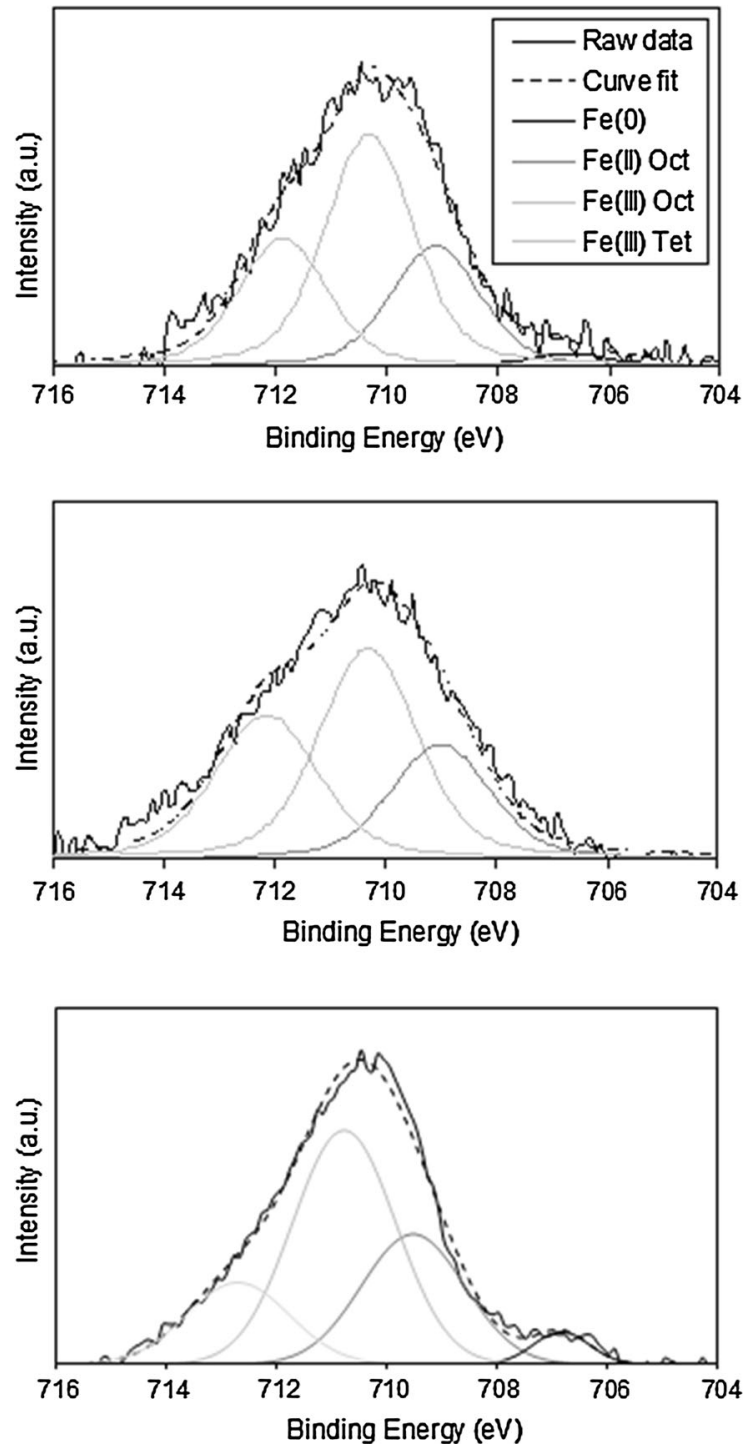

Fig. 2 X-ray photoelectron spectroscopy (XPS) $\mathrm{Fe} 2 \mathrm{p}_{3 / 2}$ photoelectron profile recorded for carbon-supported nZVI that has been vacuum annealed at $700{ }^{\circ} \mathrm{C}$ (top) and $600{ }^{\circ} \mathrm{C}$ (middle), along with borohydride-reduced nZVI (bottom)

Analysis of aqueous samples using ICP-AES extracted during period intervals recorded maximum Fe concentrations in all systems within the first $48 \mathrm{~h}$ of reaction (Fig. 6), which is attributed to the rapid corrosion of nanoparticulate surfaces. Greater $\mathrm{Fe}$ dissolution was recorded for batch systems (the groundwater and the uranyl-only solution) containing CS nZVI that had been formed at $600{ }^{\circ} \mathrm{C}$, with a maximum of 1.56 and $2.08 \mathrm{mg} \mathrm{L}^{-1}$ recorded, respectively, compared to only 0.20 and $0.51 \mathrm{mg} \mathrm{L}^{-1}$ recorded for the CS nZVI that had been formed at $700{ }^{\circ} \mathrm{C}$. This is attributed to the dissolution of residual ferric citrate trihydrate $\left[2 \mathrm{Fe}\left(\mathrm{C}_{6} \mathrm{H}_{5} \mathrm{O}_{7}\right) \cdot \mathrm{H}_{2} \mathrm{O}\right]$ present in the CS nZVI that had been formed at $600{ }^{\circ} \mathrm{C}$.

\section{Discussion}

Analysis of the bulk structure, particle size and chemical composition of CS nZVI synthesised at 600 and $700{ }^{\circ} \mathrm{C}$ using BET surface area analysis, TEM, XPS and XRD recorded three key differences between the two nanoparticle types: (i) a greater proportion of surface oxide $\mathrm{Fe}^{2+}$ to $\mathrm{Fe}^{3+}$ recorded for the nanoparticles formed at $700{ }^{\circ} \mathrm{C}(0.28$ compared to 0.34); (ii) a greater conversion of ferric citrate trihydrate $\left[2 \mathrm{Fe}\left(\mathrm{C}_{6} \mathrm{H}_{5} \mathrm{O}_{7}\right) \cdot \mathrm{H}_{2} \mathrm{O}\right]$ to $\mathrm{Fe}^{0}$ recorded for the nanoparticles formed at $700{ }^{\circ} \mathrm{C}$; and (iii) a larger surface area recorded for the nanoparticles formed at $700{ }^{\circ} \mathrm{C}$ (108.67 compared to $\left.88.61 \mathrm{~m}^{2} \mathrm{~g}^{-1}\right)$. It remains unclear which difference between would have contributed the most to the $U$ uptake ability exhibited by CS nZVI formed at $700{ }^{\circ} \mathrm{C}$. Regarding the first difference, the electrode potential of structural $\mathrm{Fe}^{2+}$ is in the range -0.65 to $0.34 \mathrm{~V}$ (Scott et al. 2010), which indicates that the oxidation of $\mathrm{Fe}^{2+}$ to $\mathrm{Fe}^{3+}$ is likely to have contributed to the chemical reduction of $\mathrm{U}^{6+}$. Indeed a number of studies have documented the reduction of $\mathrm{U}^{6+}$ to $\mathrm{U}^{4+}$ by structural (solid) $\mathrm{Fe}^{2+}$ (e.g. Fiedor et al. 1998). The relatively small difference in $\mathrm{Fe}^{2+}$ to $\mathrm{Fe}^{3+}$ ratios recorded for the CS nZVI synthesised at 600 and $700{ }^{\circ} \mathrm{C}(0.34$ and 0.28 , respectively), however, is likely to have caused this to have relatively negligible difference on the differential U uptake recorded. Regarding the second difference, it is likely that the greater conversion of $2 \mathrm{Fe}\left(\mathrm{C}_{6} \mathrm{H}_{5} \mathrm{O}_{7}\right) \cdot \mathrm{H}_{2} \mathrm{O}$ to $\mathrm{Fe}^{0}$ recorded for the CS nZVI synthesised at $700{ }^{\circ} \mathrm{C}$ would have enhanced U uptake via two closely coupled mechanisms: (i) the greater quantity of $\mathrm{Fe}^{0}$ would have allowed the material to exhibit greater chemical reducing capability and also a greater $\mathrm{Fe}^{2+}$ source for further $\mathrm{U}$ removal and chemical reduction (Charlet et al. 1998); and (ii) the lower quantity of residual $\left.2 \mathrm{Fe}\left(\mathrm{C}_{6} \mathrm{H}_{5} \mathrm{O}_{7}\right) \cdot \mathrm{H}_{2} \mathrm{O}\right)$ would limit the aqueous formation of citric acid $\left(\mathrm{C}_{6} \mathrm{H}_{8} \mathrm{O}_{7}\right)$ which is a well-known chelator of both $\mathrm{Fe}$ and $\mathrm{U}$. Table 4 lists the stability constants for aqueous $\mathrm{U}^{6+}$ in the presence and absence of citric acid. It is shown that 

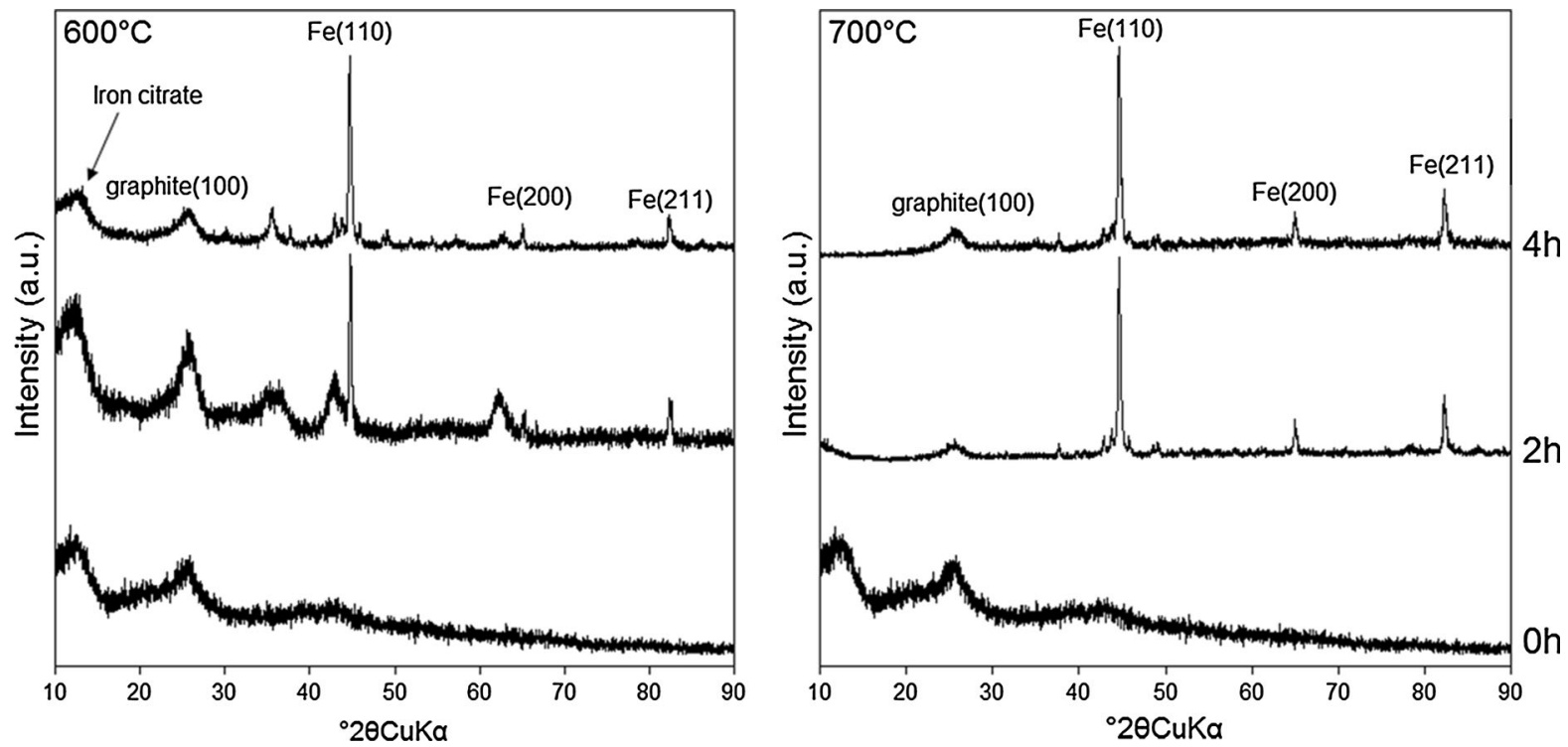

Fig. 3 X-ray diffraction (XRD) spectra (for the range of 10-90 2 2 ) recorded for the carbon-supported nZVI heated at 600 (LHS) and $700{ }^{\circ} \mathrm{C}$ (RHS) for $0 \mathrm{~h}$ (bottom), $2 \mathrm{~h}$ (middle) and $4 \mathrm{~h}($ top $)$

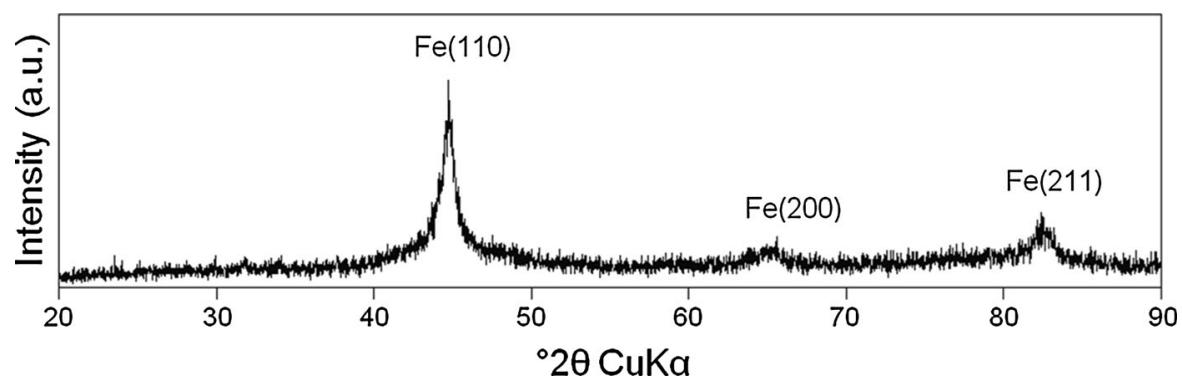

Fig. 4 X-ray diffraction (XRD) spectra (for the range of $10-90^{\circ} 2 \theta$ ) recorded for the borohydride-reduced nZVI

citric acid significantly raises the aqueous stability of uranyl.

With regard to the third difference, it is welldocumented that because aqueous contaminant sorption and chemical reduction on nZVI (and carbonsupported nZVI) is a surface-mediated process, the rate of contaminant uptake is therefore proportional to the surface area of the nanomaterial (Crane and Scott 2012). The higher surface area of the CS nZVI synthesised at $700{ }^{\circ} \mathrm{C}$ is therefore likely to have contributed to the increased capacity (or maxima) of the $\mathrm{U}$ uptake recorded. As discussed by Hoch et al. (2008), the differential surface area of the two materials is likely to have been due to an increase in the porosity of the carbon support due to carbonisation during the vacuum annealing process.

Lower maximum $U$ removal was recorded for the CS nZVI synthesised at $700{ }^{\circ} \mathrm{C}$ than the borohydridereduced nZVI. This is attributed in part due to the lower mass percentage of $\mathrm{Fe}^{0}$ in the former material. In addition, the kinetics of $\mathrm{U}$ uptake was recorded as slower for the CS nZVI, indicating that there was a lower density of surface sites for $U$ sorption. A concurrent lower decrease in solution Eh and DO was recorded for both types of CS nZVI in comparison to the borohydride-reduced nZVI, indicating that the 
Fig. 5 Changes in solution Eh, DO and $\mathrm{pH}$ as a function of reaction time $(0-672 \mathrm{~h})$ for the batch systems containing the different nZVI used in the current work. The control (nanoparticle free) batch system (not shown) recorded an Eh variation of $<10 \mathrm{mV}$, a DO variation of $<0.2 \mathrm{mg} \mathrm{L}^{-1}$ and a $\mathrm{pH}$ variation of $<0.05$ from the starting solution

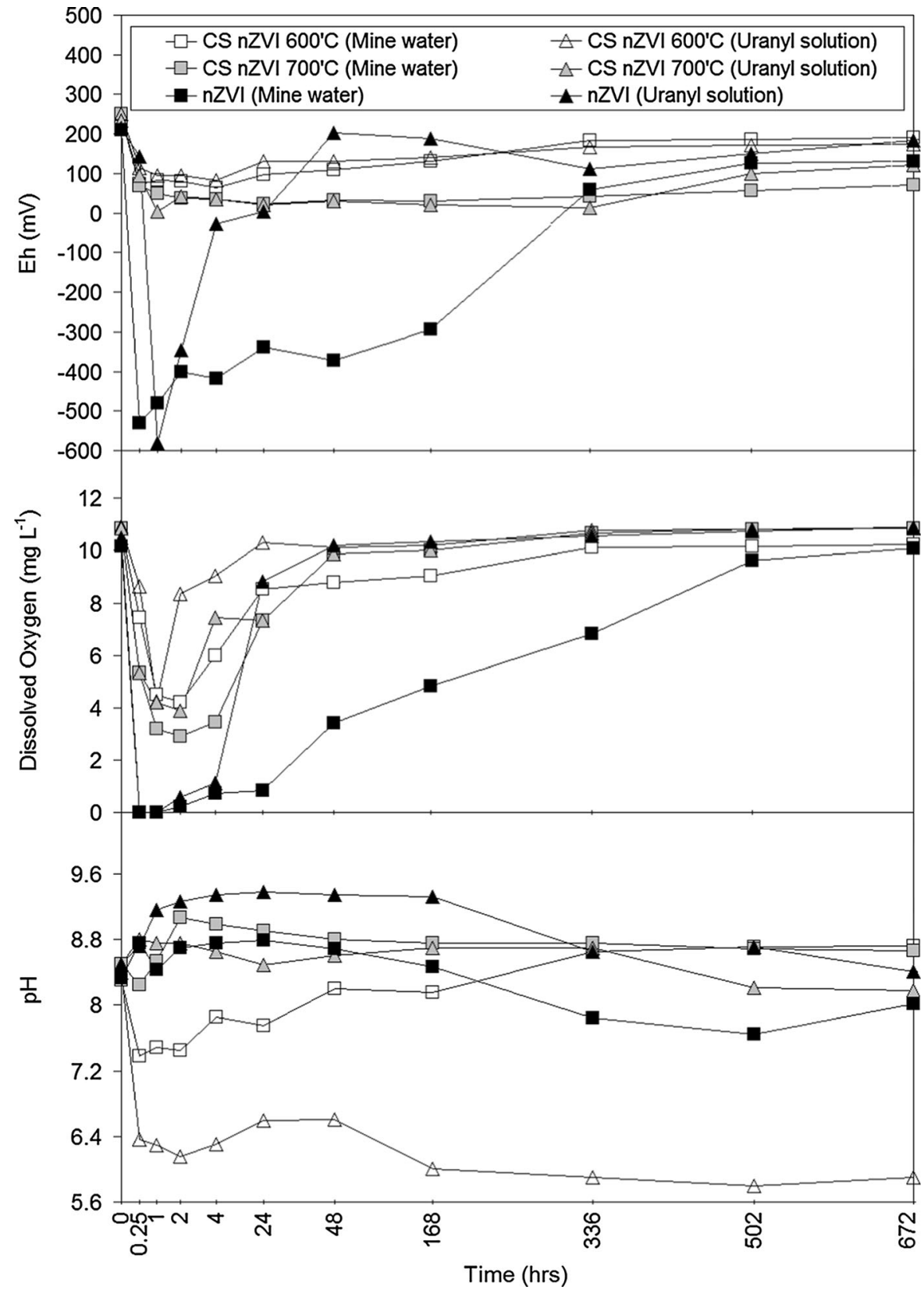

former exhibited a lower ability for $\mathrm{U}$ reduction. Despite this, lower U desorption in the latter stages of the experiment ( $>7$ days) was recorded for the CS nZVI synthesised at $700{ }^{\circ} \mathrm{C}$. The specific mechanism for this differential $\mathrm{U}$ uptake behaviour remains unclear, however, it is tentatively suggested that the presence of carbon black in the CS nZVI also contributed to the U removal, and may have limited the desorption of $U$. This was not unexpected given the well-documented association between carbon-based materials and aqueous uranium (Mossman et al. 1993; Nagy et al. 1998).

\section{Conclusions}

In the current work, carbon-supported nanoscale zerovalent iron particles (CS nZVI) have been tested for the 
Fig. 6 Changes in solution $\mathrm{U}$ and $\mathrm{Fe}$ concentration as a function of reaction time $(0-672 \mathrm{~h})$ for the batch systems containing the different nZVI used in the current work. The aqueous U control (nanoparticle free) batch system (not shown) recorded a variation of $<1 \mathrm{mg} \mathrm{L}^{-1}$ from the starting solution concentrations

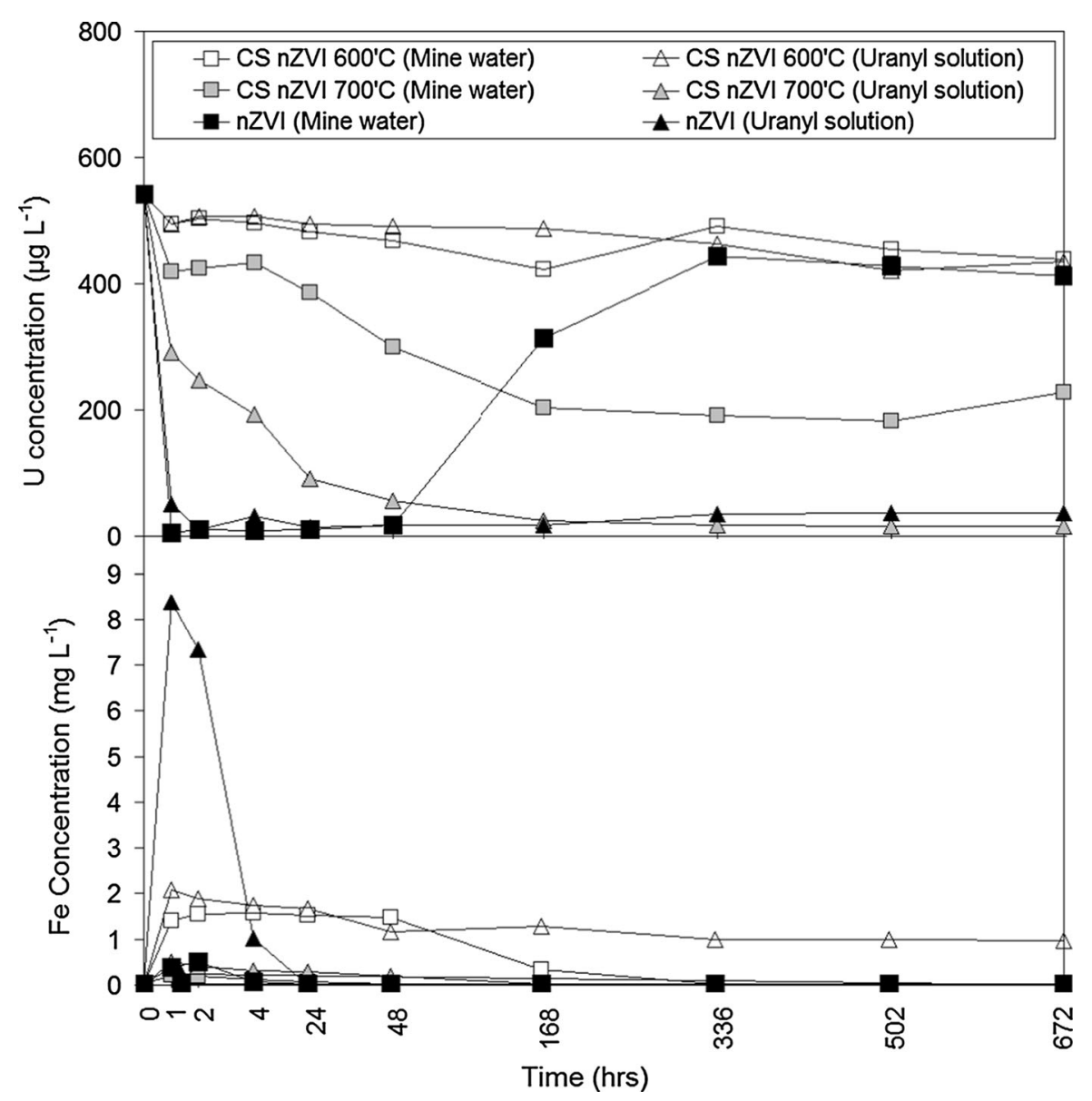

Table 4 Stability constants $(\log \mathrm{K})$ of aqueous $\mathrm{U}^{6+}$ in the presence and absence of citric acid

\begin{tabular}{lcr}
\hline Association reaction & Log K & Eq. \\
\hline $\mathrm{UO}_{2}{ }^{2+}+\mathrm{H}_{2} \mathrm{O}=\mathrm{UO}_{2} \mathrm{OH}^{+}+\mathrm{H}^{+}$ & $-5.2^{\mathrm{a}}$ & 3 \\
$\mathrm{UO}_{2}{ }^{2+}+2 \mathrm{H}_{2} \mathrm{O}=\mathrm{UO}_{2}(\mathrm{OH})_{2}+2 \mathrm{H}^{+}$ & $-12.0^{\mathrm{a}}$ & 4 \\
$\mathrm{UO}_{2}{ }^{2+}+3 \mathrm{H}_{2} \mathrm{O}=\mathrm{UO}_{2}(\mathrm{OH})_{3}^{-}+3 \mathrm{H}^{+}$ & $-19.2^{\mathrm{a}}$ & 5 \\
$\mathrm{UO}_{2}{ }^{2+}+\mathrm{cit}^{3-}=\mathrm{UO}_{2} \mathrm{cit}^{-}$ & $8.74^{\mathrm{a}}$ & 6 \\
$2 \mathrm{UO}_{2}{ }^{2+}+\mathrm{cit}^{3-}=\left(\mathrm{UO}_{2}\right)_{2}(\mathrm{cit})_{2}^{2-}$ & $21.3^{\mathrm{b}}$ & 7 \\
$\mathrm{H}_{3} \mathrm{cit}^{2-} \mathrm{cit}^{3-}+3 \mathrm{H}^{+}$ & $-14.29^{\mathrm{c}}$ & 8 \\
$\mathrm{H}_{2} \mathrm{cit}^{2}=\mathrm{cit}^{3-}+2 \mathrm{H}^{+}$ & $-11.16^{\mathrm{c}}$ & 9 \\
$\mathrm{Hcit}^{2-}=\mathrm{cit}^{3-}+\mathrm{H}^{+}$ & $-6.39^{\mathrm{c}}$ & 10
\end{tabular}

${ }^{a}$ Kantar et al. (2005), ${ }^{b}$ Smith and Martell (1993) and ${ }^{c}$ Field et al. (1974)

removal of $U$ from natural and synthetic waters. Two types of CS nZVI were tested, one type that has been vacuum annealed at $600{ }^{\circ} \mathrm{C}$ for $4 \mathrm{~h}$ and the other type that has been vacuum annealed at $700{ }^{\circ} \mathrm{C}$ for $4 \mathrm{~h}$, with their aqueous reactivity and associated $\mathrm{U}$ uptake behaviour compared to nZVI synthesised via the reduction of ferrous iron using sodium borohydride. Results highlight a clear difference in reactivity between the two types of CS nZVI, with greater U removal exhibited by the nanoparticles synthesised at $700{ }^{\circ} \mathrm{C}$. The mechanism has been attributed to the CS nZVI synthesised at $700{ }^{\circ} \mathrm{C}$ exhibiting (i) a greater proportion of surface oxide $\mathrm{Fe}^{2+}$ to $\mathrm{Fe}^{3+}(0.34$ compared to 0.28 ); (ii) a greater conversion of ferric citrate trihydrate $\left[2 \mathrm{Fe}\left(\mathrm{C}_{6} \mathrm{H}_{5} \mathrm{O}_{7}\right) \cdot \mathrm{H}_{2} \mathrm{O}\right]$ to $\mathrm{Fe}^{0}$; and (iii) a larger surface area (108.67 compared to $\left.88.61 \mathrm{~m}^{2} \mathrm{~g}^{-1}\right)$.

In comparison with the borohydride-reduced nZVI, lower maximum $\mathrm{U}$ uptake was recorded for both types of CS nZVI. A concurrent lower decrease in solution Eh and DO was recorded for both types of CS nZVI in comparison to the borohydride-reduced nZVI, indicating that lower chemical reduction of $U$ was achieved by 
the former. This is attributed to the lower mass percentage of ZVI in the CS nZVI, decreasing the chemical reduction ability of the nanoparticles. Despite this, lower $U$ desorption in the latter stages of the experiment ( $>7$ days) was recorded for the CS nZVI synthesised at $700{ }^{\circ} \mathrm{C}$. The specific mechanism for this differential U uptake behaviour remains unclear, however, it is tentatively suggested that the presence of carbon black in the CS nZVI provided an addition site for $\mathrm{U}$ retention. Future work will seek to examine this hypothesis. Overall, it can be concluded that the borohydride-reduced nZVI were more effective than CS nZVI for U removal over relatively short timescales (e.g. $<48 \mathrm{~h}$ ), however, they were more susceptible to $\mathrm{U}$ desorption over extended time periods.

Acknowledgments We would like to thank Mr. Jonathan Jones from the School of Chemistry, University of Bristol for performing TEM analysis. We would also like to thank the National Company Uranium (Romania), namely Mr. Valentin Calen, for providing mine water samples for the current work, and scientists from the National Institute for Metals and Radioactive Resources, Bucharest, Romania, namely Mrs. Ioana Popescu and Mr. Madalin Silion, for help with arranging delivery of the mine water samples to the University of Bristol. This work was financially supported by the Engineering and Physical Sciences Research Council through the Doctoral Training Grant and the North Atlantic Treaty Organization through the Co-operative Science and Technology Sub-Programme (CLG982551).

Open Access This article is distributed under the terms of the Creative Commons Attribution License which permits any use, distribution, and reproduction in any medium, provided the original author(s) and the source are credited.

\section{References}

Abbasi WA, Streat M (1994) Adsorption of uranium from aqueous solutions using activated carbon. Sep Sci Technol 29:1217-1230

Cantrell KJ, Kaplan DI, Wietsma TW (1995) Zero-valent iron for the in situ remediation of selected metals in groundwater. J Hazard Mater 42:201-212

Charlet L, Liger E, Gerasimo P (1998) Decontamination of TCE- and U-rich waters by granular iron: role of sorbed Fe(II). J Environ Eng 124:25-30

Chen C, Li X, Zhao D, Tan X, Wang X (2007) Adsorption kinetic, thermodynamic and desorption studies of Th(IV) on oxidized multi-wall carbon nanotubes. Colloids Surf A 302:449-454

Choi H, Agarwal S, Al-Abed SR (2009) Adsorption and simultaneous dechlorination of $\mathrm{PCBs}$ on $\mathrm{GAC} / \mathrm{Fe} / \mathrm{Pd}$ : mechanistic aspects and reactive capping barrier concept. Environ Sci Technol 43:488-493

Crane RA, Noubactep C (2012) Elemental metals for environmental remediation: lessons from hydrometallurgy. Fresen Env Bull 21:1192-1196

Crane RA, Scott TB (2012) Nanoscale zero-valent iron: future prospects for an emerging water treatment technology. J Hazard Mater 211:112-125

Crane RA, Scott TB (2013) The effect of vacuum annealing of magnetite and zero-valent iron nanoparticles on the removal of aqueous uranium J Nanotech 2013:1-11 Article ID 173625. doi:10.1155/2013/173625

Crane RA, Scott TB (2014) The removal of uranium onto nanoscale zero-valent iron particles in anoxic batch systems. J Nanomater 2014:1-9. doi:10.1155/2014/956360

Crane RA, Dickinson M, Popescu IC, Scott TB (2011) Magnetite and zero-valent iron nanoparticles for the remediation of uranium contaminated environmental water. Water Res 45:2931-2942

Crane RA, Dickinson M, Scott TB (2015) Nanoscale zero-valent iron particles for the remediation of plutonium and uranium contaminated solutions. Chem Eng J 262:319-325

Dickinson M, Scott TB, Crane RA, Riba O, Barnes R, Hughes G (2010) The effects of vacuum annealing on the structure and surface chemistry of iron:nickel alloy nanoparticles. J Nano Res 12:2081-2092

Fiedor JN, Bostick WD, Jarabek RJ, Farrell J (1998) Understanding the mechanism of uranium removal from groundwater by zero-valent iron using X-ray photoelectron spectroscopy. Environ Sci Technol 32:1466-1473

Field TB, McCourt JL, McBryde WAE (1974) Composition and stability of iron and copper citrate complexes in aqueous solution. Can J Chem 52:3119-3124

Grovesnor AP, Kobe BA, Biesinger MC, McIntyre NS (2004) Investigation of multiplet splitting of Fe $2 p$ XPS spectra and bonding in iron compounds. Surf Interface Anal 36:1564-1574

Gu B, Liang L, Dickey MJ, Yin X, Dai S (1998) Reductive precipitation of uranium(VI) by zero-valent iron. Environ Sci Technol 32:3366-3373

Hoch LB, Mack EJ, Hydutsky BW, Hershman JM, Skluzacek JM, Mallouk TE (2008) Carbothermal synthesis of carbonsupported nanoscale zero-valent iron particles for the remediation of hexavalent chromium. Environ Sci Technol 42:2600-2605

Jabeen H, Chandra V, Jung S, Lee JW, Kim KS, Kim SB (2011) Enhanced $\mathrm{Cr}(\mathrm{VI})$ removal using iron nanoparticle decorated graphene. Nanoscale 3:3583-3585

Kantar C, Gillow JB, Harper-Arable R, Honeyman BD, Francis AJ (2005) Determination of stability constants of U(VI)$\mathrm{Fe}(\mathrm{III})$-citrate complexes. Environ Sci Technol 39: 2161-2168

Kumar S, Loganathan VA, Gupta RB, Barnett MO (2011) An assessment of $\mathrm{U}(\mathrm{VI})$ removal from groundwater using biochar produced from hydrothermal carbonization. J Environ Manag 92:2504-2512

Li ZH, Jones HK, Zhang PF, Bowman RS (2007) Chromate transport through columns packed with surfactant-modified zeolite/zero valent iron pellets. Chemosphere 68:1861-1866 
Lv X, Xu J, Jiang G, Xu X (2011) Removal of chromium(VI) from wastewater by nanoscale zero-valent iron particles supported on multiwalled carbon nanotubes. Chemosphere 85:1204-1209

Mellah A, Chegrouche S, Barkat M (2006) The removal of uranium(VI) from aqueous solutions onto activated carbon: kinetic and thermodynamic investigations. J Colloid Interface Sci 296:434-441

Mossman DJ, Najy B, Davis DW (1993) Hydrothermal alteration of organic matter in uranium ores, Elloit Lake, Canada: implications for selected organic-rich deposits. Geochim Cosmochim Acta 57:3251-3259

Nagy B, Gauthier-Lafaye F, Holliger P, Davis DW, Mossman DJ, Leventhal JS, Rigali MJ, Parnell J (1998) Organic matter and containment of uranium and fissiogenic isotopes at the Oklo natural reactors. Nature 354:472-475

O'Loughlin EJ, Kelly SD, Cook RE, Csencsits R, Kemner KM (2003) Reduction of uranium (VI) by mixed iron(II)/iro$\mathrm{n}$ (III) hydroxide (green rust): formation of $\mathrm{UO}_{2}$ nanoparticles. Environ Sci Technol 37:721-727

Ponder SM, Darab JG, Mallouk TE (2000) Remediation of $\mathrm{Cr}(\mathrm{VI})$ and $\mathrm{Pb}(\mathrm{II})$ aqueous solutions using nanoscale zerovalent iron. Environ Sci Technol 34:2564-2569

Ragnarsdottir K, Charlet L (2000) Uranium behaviour in natural environments. Environmental mineralogy-microbial interactions, anthropogenic influences, contaminated land and waste management. Mineralog Soc Ser 9:245-289

Rahman RO, Ibrahium HA, Hung Y-T (2011) Liquid radioactive wastes treatment: a review. Water 3:551-565

Riba O, Scott TB, Ragnarsdottir KV, Allen GC (2008) Reaction mechanism of uranyl in the presence of zero-valent iron nanoparticles. Geochim Cosmochim Acta 72:4047-4057

Scott TB, Dickinson M, Crane RA, Riba O, Hughes G, Allen G (2010) The effects of vacuum annealing on the structure and surface chemistry of iron nanoparticles. J Nano Res 12:2081-2092

Scott TB, Popescu IC, Crane RA, Noubactep C (2011) Nanoscale metallic iron for the treatment of solutions containing multiple inorganic contaminants. J Hazard Mater 186:280-287

Sheng G, Shao X, Li Y, Li J, Dong H, Cheng W, Gao X, Huang Y (2014) Enhanced removal of uranium(VI) by nanoscale zerovalent iron supported on $\mathrm{Na}-$ bentonite and an investigation of mechanism. J Phys Chem A 118:2952-2958

Shin Y, Bae S, Lee W (2013) Formation of surface mediated iron colloids during U(VI) and nZVI interaction. Adv Environ Res 2:167-177

Smith RM, Martell AE (1993) NIST Critical Stability constants of metal complexes database; NIST Standard Reference Database 46. U.S. Department of Commerce, Gaithersburg

Suna Y, Ding C, Cheng W, Wang X (2014) Simultaneous adsorption and reduction of $\mathrm{U}(\mathrm{VI})$ on reduced graphene oxide-supported nanoscale zerovalent iron. J Hazard Mater 280:399-408

Üzüm C, Shahwan T, Eroğlu AE, Hallam KR, Scott TB, Lieberwirth I (2009) Synthesis and characterization of kaolinite-supported zero-valent iron nanoparticles and their application for the removal of aqueous $\mathrm{Cu}^{2+}$ and $\mathrm{Co}^{2+}$ ions. Appl Clay Sci 43:172-181

Wang CB, Zhang WX (1997) Synthesizing nanoscale iron particles for rapid and complete dechlorination of TCE and PCBs. Environ Sci Technol 31:2154-2156

Wang Y-Q, Zhang Z-B, Liu Y-H, Cao X-H, Liu Y-T, Li Q (2012) Adsorption of U(VI) from aqueous solution by the carboxyl-mesoporous carbon. Chem Eng J 198-199: 246-253

Yan S, Hua B, Bao ZY, Yang J, Liu CX, Deng BL (2010) Uranium (VI) removal by nanoscale zerovalent iron in anoxic batch systems. Environ Sci Technol 44:7783-7789

Yan S, Chen Y, Xiang W, Bao Z, Liu C, Deng B (2014) Uranium(VI) reduction by nanoscale zero-valent iron in anoxic batch systems: the role of $\mathrm{Fe}(\mathrm{II})$ and $\mathrm{Fe}(\mathrm{III})$. Chemosphere 117:625-630

Zhang W-x (2003) Nanoscale iron particles for environmental remediation: an overview. J Nano Res 5:323-332 